\title{
Introduction: Mani's Church and Social Life
}

\begin{abstract}
Zarades was sent to Persia, to Hystaspes the king. He revealed the truly-founded law in all of Persia. Again, Bouddas the blessed, he came to the land of India and Kushan. He also revealed the truly-founded law in all of India and Kushan. After him again, Aurentes came with Kebellos to the east. They also revealed the truly-founded law in the east. Elchasai (?) came to Parthia. He revealed the law of truth in all of Parthia. Jesus the Christ came to the west. He also revealed the truth in all of the west.... I came; I revealed this place (i.e. the Land of Light) in this world. I preached the word of God. And I [...] of God in the world from the west to [the east.] ${ }^{1}$
\end{abstract}

The above words are ascribed to Mani, eponymous founder of Manichaeism, and contained in a papyrus codex discovered at Medinet Madi in Middle Egypt. Other text, from this and related codices, describe a fantastically detailed system of divine and demonic forces. They reveal the scope of this tradition as it was envisioned by some of his Egyptian adherents: one that covered the whole known world, embraced and surpassed all previous traditions, and explained all things in heaven and earth. It is difficult to find a religion seemingly more at odds with the local, lived, or material aspects of religion on which recent scholarly trends have focused, and it is perhaps not surprising that everyday social practice has largely received little attention within the study of Manichaeism. The recent discoveries at Ismant el-Kharab have provided a unique opportunity to change this: to re-evaluate scholarly assumptions about the movement, and to explore the relationship between ideal and practice, between the 'great tradition' and daily life. The present work aims to contribute to this endeavour.

\section{Mani's Church}

Before we move on to consider the sources, methodology, and scholarly debates on which this study builds, a presentation of Mani, his revelations and his movement, is in order. While our knowledge is still far from complete, its

12 Ke. 423.3-424.14 (abridged), trans. Iain Gardner, Jason D. BeDuhn, and Paul Dilley, eds., The Chapters of the Wisdom of My Lord Mani (Leiden: Brill, 2018). 
history, rituals, and tenets are much better understood today than a century or even a few decades ago, due to a growing body of scholarly works on which the present study builds. ${ }^{2}$

Mani (c.216-277) was a Syriac-speaking subject of the Sasanian Empire, who grew up in a Jewish-Christian 'baptist' community in Mesopotamia, linked to a shadowy prophet named Elchasai. ${ }^{3}$ His life is generally told in terms of his revelations. In his 13th year, Mani received the first in a series of revelations brought by his divine, heavenly Twin. In his 25 th year, around $240 \mathrm{CE}$, another revelation caused him to leave the baptists, after heated conflict within the community. The next 35 years saw him travelling extensively, preaching his revelations and administering to a growing number of followers in the Sasanian Empire and beyond, while presenting himself as the Apostle of Jesus Christ. Christianity played a key part in his mission, but he also drew on others traditions, a point to which we return below. At some point, he secured approval from the Sasanian king, Shapur I (reign c.24O-271). ${ }^{4}$ But in 277 , the then-reigning king Bahram II had him chained. According to his followers, Mani died after 26 days of imprisonment and torture. ${ }^{5}$ His death was accompanied by persecutions, but by then adherents of his movement had spread far and wide - Egypt being one of their earliest centres in the Roman Empire.

The revelations had presented him with a dualistic vision of the cosmos: here raged a war between two opposing 'natures' or 'realms', Light (Spirit) and

2 For such overviews, see Samuel N. C. Lieu, Manichaeism in the Later Roman Empire and Medieval China (Manchester: Manchester University Press, 1985); Michel Tardieu, Manichaeism, trans. M. B. Devoise (Urbana: University of Illinois Press, 20o8), both originally published in the 1980 os. A more recent introduction is found in Nicholas J. Baker-Brian, Manichaeism: An Ancient Faith Rediscovered (London: Continuum International Publishing, 2011). For the life of Mani, see most recently Iain Gardner, The Founder of Manichaeism: Rethinking the Life of Mani (Cambridge: Cambridge University Press, 2020). For a survey of work in the field, already somewhat dated, see Andrew Wearring, 'Manichaean Studies in the 21st Century', in Through a Glass Darkly: Reflections on the Sacred, ed. Frances di Lauro (Sydney: Sydney University Press, 2006).

3 For a dissenting view, maintaining a distinction between these 'baptists' and Elchasai, cf. Gerard P. Luttikhuizen, 'The Baptists of Mani's Youth and the Elchasaites', in Gnostic Revisions of Genesis Stories and Early Jesus Traditions (Leiden: Brill, 2006).

4 The date of the meeting and the extent of Shapur I's approval is unknown. See Paul C. Dilley, 'Mani's Wisdom at the Court of the Persian Kings', in Mani at the Court of the Persian Kings, ed. Iain Gardner, Jason D. BeDuhn, and Paul Dilley (Leiden: Brill, 2015), 39-41.

5 Scholarly debate has surrounded the year of his death. It has to be calculated from the date solemnised by the Manichaean Church, which claimed to preserve the exact time of death: the eleventh hour, Monday, fourth of the month Adar. If this tradition was correct, a dating of this event to $277 \mathrm{CE}$, Monday 26th February, by our calendar, seems now to be supported by the Dublin Kephalaia; see Iain Gardner, 'Mani's Last Days', in Mani at the Court of the Persian Kings, ed. Iain Gardner, Jason D. BeDuhn, and Paul Dilley (Leiden: Brill, 2015), 203-5. 
Darkness (Matter). Manichaean discourse presented this war in a tripartite mythic scheme known as 'the three times. ${ }^{6}$ Time begun when the demons of Darkness attacked the Light, disturbing the primeval equilibrium. The highest God, the Father of Lights, emanated divinities to defend his realm, but in the ensuing battle the combatants became mixed. Next, a new series of divinities shaped demonic Matter into a vehicle for separating the two, creating the world. Surviving demons retaliated, however; the trapped Light became further divided, bound in the material bodies of humans, animals, plants, and soil. The war continues as divinities seek to free these Light Souls. ${ }^{7}$ Third, the Light will, in the future, achieve its victory: a final separation of the two substances, where all souls are reunited with the Light and all creatures of Darkness are bound and imprisoned.

In the course of his life, Mani presented his evolving body of teachings in books, traditionally numbered seven, with accounts of his experiences, myths, parables, theological arguments, letters, hymns, prayers, and even paintings. ${ }^{8}$ Not least, he formed a community, in western sources referred to as an ekklesia (Gr. $\varepsilon \varkappa \varkappa \lambda \eta \sigma i \alpha)$, i.e. a 'Church', to preserve the teachings and promote the salvation of souls. It is here that we find the blue print for Manichaean social organisation. It was envisioned in terms of a basic twofold structure, divided into an ascetic elite, 'the righteous' or 'the chosen ones' (Elect), and lay-followers, 'catechumens' or 'hearers' (Auditors). ${ }^{9}$ The Elect performed 'the work of the religion', committing to rituals and ascetic discipline. ${ }^{10}$ They were to abstain from eating meat, drinking alcohol, owning property, or consuming more food than necessary for their daily needs. They should not harm living beings

6 See Iris Colditz, 'The Abstract of a Religion or: What Is Manichaeism?', in Mani in Dublin: Selected Papers from the Seventh International Conference of the International Association of Manichaean Studies in the Chester Beatty Library, Dublin, 8-12 September 2009, ed. S. G. Richter, C. Horton, and K. Ohlhafer (Leiden: Brill, 2015).

7 It should be emphasised that his notion of 'Light Souls' does not correspond to the mainstream Christian (or Neoplatonist) one of the soul. Light Souls are a visible, physical substance, seen for instance in the divine 'light-givers', the sun and moon.

8 None have been preserved in their entirety. For scholarship on the 'canon' of Mani, see Gregor Wurst, 'Létat de la recherche sur le canon manichéen', in Le canon du Nouveau Testament: regards nouveaux sur l'histoire de sa formation, ed. Gabriella Aragione, Eric Junod, and Enrico Norelli (Genève: Labor et Fides, 2005).

9 I here largely follow Jason D. BeDuhn's usage of the terms 'Auditor' and 'Elect'; see furthermore Jason D. BeDuhn, The Manichaean Body: In Discipline and Ritual (Baltimore: Johns Hopkins University Press, 2000), 25-30.

10 See Nicholas Sims-Williams, 'The Manichaean Commandments: A Survey of the Sources', in Papers in Honour of Professor Mary Boyce, ed. A. D. H. Bivar (Leiden: Brill, 1985); BeDuhn, The Manichaean Body, 33-53; Andrea Piras, 'Sealing the Body: Theory and Practices of Manichaean Asceticism', Religion in the Roman Empire 4 (2018). 
(including by tilling soil or picking fruit), indulge in harmful passions, such as sexual intercourse, or speak blasphemies. Instead, they were to fast, preach, sing hymns, offer weekly confessions, read and copy scripture, and travel continuously, living a life of 'blessed poverty'. In this way, their souls tamed their material bodies, and made them capable of releasing Light. Once a day they consumed a vegetarian meal through which they purified Light, freeing it from the cycle of rebirths that kept it imprisoned in Matter. ${ }^{11} \mathrm{~A}$ hierarchy of 12 Teachers, 72 bishops, and presbyters, all presided over by a single leader called

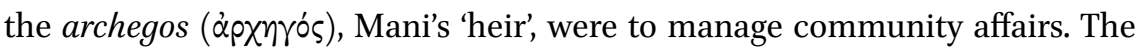
majority of adherents, the Auditors, took on duties in accordance with their abilities. Their most important task was to assist the Elect with all their needs: clothes, recruits, shelter, and their daily, ritual meal. As a consequence, the Auditors themselves got to take part in the liberation of Light, bringing them closer to their future salvation.

This is what may be termed the 'canonical' depiction of the Manichaean community, reconstructed by scholars on the basis of a variety of sources. But was this the entity that most lay Manichaeans knew? Did they identify as part of a far-flung movement, represented by an Elect hierarchy, rooted in the revelations of Mani and originating in distant Mesopotamia? How distinct did they consider their religious practice to be from that of their non-Manichaean neighbours? We return to the scholarly debate concerning these questions, but first we need to briefly survey the sources that have laid the premises for this debate: the Manichaean material from Egypt and the recent discoveries at Kellis, in particular.

\section{The Sources}

\subsection{Egyptian Manichaean Texts}

Most of the information available to early scholars was derived from fourth-century patristic writers such as Epiphanius of Salamis, pseudoHegemonius, and especially Augustine (354-430), bishop of Hippo Regius in today's Algeria. Augustine was an erstwhile adherent of Mani, having become so as a young student in Carthage in 373, but he gradually lost faith in the movement and in 386 made his famous 'conversion' to Christianity.12 As a bishop

\footnotetext{
11 See in particular BeDuhn, The Manichaean Body, 163-87.

12 For a recent take on Augustine's 'de-conversion', see Jason D. BeDuhn, Augustine's Manichaean Dilemma. Vol. I: Conversion and Apostasy, 373-388 C.E. (Philadelphia: University of Pennsylvania Press, 2010). For other recent work on Autustine and
} 
of the 'Catholic' Church, he became a merciless critic of Manichaean beliefs and practices. Polemical writings against the movement make up a respectable part of his preserved writings. More detached, although from a later period, are the works of Muslim scholars touching on the tradition, which came to scholarly attention in the second half of the 19th century - foremost among them, Abu al-Faraj Muḥammad ibn Isḥāhaq al-Nadim's Fihrist. ${ }^{13}$

Manichaean 'insider' texts with which to compare these sources only appeared in the 2oth century. The first discoveries were made by European and Japanese expeditions to the Turfan Basin (in today's western China) in the early 19oos, bringing to light a large Manichaean literature written in Iranian, Chinese, and Turkic languages. In the west, a Manichaean treatise in Latin was first found in a cave outside Tebessa (Algeria) in 1918. To date, however, the most important western Manichaean texts are those that were found at Medinet Madi, a site in the Fayyum in Middle Egypt known as Narmouthis in the Roman era. This find consisted of seven (or so) codices, found by local workers around 1929, acquired by European and American buyers in Cairo in 1930-31, and announced to the scholarly world in 1933 by Carl Schmidt and Hans J. Polotsky. Some landed in London (later Dublin), others Berlin. ${ }^{14}$ All were written in a dialect of Coptic linked to Upper Egypt, and date $c .400$, although the texts within are mostly translations of earlier works. They include:

- One collection of Mani's Epistles (the Epistle codex)

- One collection of Church historical narratives (the Acts codex)

- One collection of excerpts from Mani's Living Gospel (the Synaxeis codex)

- One collection of homilies (the Homilies codex)

- One large collection of psalms (the Psalm-book, split in two: 1 and 2 Ps)

Manichaeism, see the studies in Johannes van Oort, Mani and Augustine: Collected Essays on Mani, Manichaeism and Augustine (Leiden: Brill, 2020).

13 By Gustav Flügel, Mani, seine Lehre und seine Schriften: Ein Beitrag zur Geschichte des Manichäismus (Leipzig: F. A. Brockhaus, 1862), published posthumously. The passages on Manichaeism is translated in Bayard Dodge, The Fihrist of al-Nadim: A Tenth-Century Survey of Muslim Culture. Vol. II (New York: Columbia University Press, 1970). See also John C. Reeves, Prolegomena to a History of Islamicate Manichaeism (Sheffield: Equinox, 2011).

14 Hans J. Polotsky, Carl Schmidt, and Hugo Ibscher, 'Ein Mani-Fund in Ägypten: Originalschriften des Mani und seiner Schüler', Sitzungsberichte der Preußischen Akademie der Wissenschaften (1933). Schmidt mentioned eight codices, but it has been assumed that the Psalm codex was split in two for sale. See James M. Robinson, The Manichaean Codices of Medinet Madi (Eugene: Cascade Books, 2013), 4; Iain Gardner, 'An Introduction to the Chester Beatty Kephalaia Codex', in Mani at the Court of the Persian Kings, ed. Iain Gardner, Jason D. BeDuhn, and Paul Dilley (Leiden: Brill, 2015), 2 n.2. 
- Two codices of theological 'chapters' (kephalaia), respectively entitled:

- The Chapters of the Teacher (1 Ke, or the Berlin Kephalaia)

- The Chapters of the Wisdom of My Lord Mani (2 Ke, the Dublin Kephalaia) A few were published before the Second World War. ${ }^{15}$ Unfortunately, the Epistles and the Acts were not among them; they were stored in Berlin and disappeared in the chaos after the war. The remaining codices were in a poor condition. While the last few decades have seen the publication and re-publication of several texts, much remains unpublished even today. ${ }^{16}$ Another Egyptian find of paramount importance is a miniature codex containing traditions, purportedly by Mani's disciples, concerning his life and missionary journeys in Greek. ${ }^{17}$

15 Hans Jakob Polotsky and Hugo Ibscher, Manichäische Homilien (Stuttgart: Kohlhammer Verlag, 1934); Hans Jakob Polotsky and Alexander Böhlig, Kephalaia (I). Erste Hälfte. Lieferung 1-10 (Stuttgart: Kohlhammer Verlag, 1940); Charles R. C. Allberry, A Manichaean Psalm-Book. Part II (Stuttgart: Kohlhammer Verlag, 1938).

16 Another fascicle of $1 \mathrm{Ke}$, based on work by Polotsky mostly completed by 1943, was published by Alexander Böhlig, Kephalaia (I). Zweite Hälfte. Lieferung 11/12. (Stuttgart: Kohlhammer Verlag, 1966). Remaining parts have been only recently published, by Wolf-Peter Funk, ed. Kephalaia I. Zweite Hälfte, Lieferung 13/14 (Stuttgart: Kohlhammer Verlag, 1999); id., Kephalaia I. Zweite Hälfte. Lieferung 15/16 (Stuttgart: Kohlhammer Verlag, 200o); id., Kephalaia I. Zweite Hälfte. Lieferung 17/18 (Stuttgart: Kohlhammer Verlag, 2018). Facsimile editions of 2 Ke were published by Søren Giversen in the 1980s; see Wolf-Peter Funk, 'Zur Faksimileausgabe der koptischen Manichaica in der Chester-Beatty-Sammlung', Orientalia 59, no. 4 (1990). Its contents were treated by Michel Tardieu, 'La diffusion de bouddhisme dans l'empire Kouchan, l'Iran et la Chine, d'après un kephalaion manichéen inédit', Studia Iranica 17 (1988). Work on a critical edition is ongoing, and a first volume has been published; Gardner, BeDuhn, and Dilley, eds., The Chapters of the Wisdom. Remaining leafs of Mani's Epistles are being edited by Gardner and Funk. For work on the Psalm-book, see Gregor Wurst, Liber Psalmorum. Pars II. Fasc. 1. Die Bêma-Psalmen (Turnhout: Brepols, 1996); Siegfried G. Richter, Liber Psalmorum. Pars II. Fasc. 2. Die Herakleides-Psalmen (Turnhout: Brepols, 1998); id., 'Arbeiten am koptisch-manichaeischen Psalmenbuch I', in Il Manicheismo. Nuove prospettive della ricera (Turnhout: Brepols, 2005). For the Homilies; Nils A. Pedersen, The Manichaean Homilies: With a Number of Hitherto Unpublished Fragments (Turnhout: Brepols, 20o6). For the Synaxeis Codex; Wolf-Peter Funk, 'Mani's Account of Other Religions According to the Coptic Synaxeis Codex', in New Light on Manichaeism, ed. Jason D. BeDuhn (Leiden: Brill, 2009).

17 Albert Henrichs and Ludwig Koenen, 'Ein griechischer Mani-Codex (P. Colon. inv. nr. 4780)', Zeitschrift für Papyrologie und Epigraphik 5 (1970); Ludwig Koenen, 'Zur Herkunft des Kölner Mani-Codex',Zeitschrift für Papyrologie und Epigraphik (1973); Albert Henrichs, 'The Cologne Mani Codex Reconsidered', Harvard Studies in Classical Philology 83 (1979). A critical edition was published in Ludwig Koenen and Cornelia Römer, Der Kölner Mani-Kodex: Über das Werden seines Leibes. Kritische Edition (Opladen: Westdeutscher Verlag, 1988); with some additional remarks and readings in Cornelia Römer, Manis frühe Missionsreisen nach der Kölner Manibibliographie: Textkritischer Kommentar und Erläuterungen zu p.121-p.192 des Kölner Mani-Kodex (Opladen: Westdeutscher Verlag, 1994). 
It came to light in Cologne, and is therefore referred to as the Cologne Mani Codex (CMC). Details surrounding its discovery are hazy, apart from the fact that it was found in (Upper) Egypt, but the publication of its discovery in 1970 provided new impetus for work on western Manichaeism.

\subsection{The Discoveries at Ismant el-Kharab}

The 197os, furthermore, saw the beginning of archaeological research in the Dakhleh Oasis. Until then, this remote region had received little attention compared to the well-known sites of the Nile Valley. European explorers first came to the Oasis in 1819, reporting on ruins and rock carvings in the area, and the American Herbert E. Winlock, who visited in 1908, provided a comprehensive account of Dakhleh. ${ }^{18}$ The ruins of Ismant el-Kharab were located and described at this time. Interest in the Oasis was renewed in the mid-2oth century by Ahmed Fakhry, one of the first Egyptian-educated archaeologists, and his work prompted Canadian archaeologists to launch the Dakhleh Oasis Project (DOP) and the Institut Français d'Archéologie Orientale (IFAO) to initiate surveys in 1977. Excavations continue until the present, and reports and conferences on Oasis archaeology have been published in the Dakhleh Oasis Project-series, and, more recently, in the Oasis Papers-series.

Excavations at Ismant el-Kharab ('Ismant the ruined') started in 1986/7. Already one of the first excavated sites, the domestic complex House 1-3, held rich deposits of papyri. The Roman-era name of the site was still unknown at this point, but these papyri showed Ismant to be the site of Kellis, a village previously known from a few, scattered papyri from the Nile Valley. Their publication has been ongoing since the mid-gos. The first volume of documentary material, P.Kellis I, was published by Klaas A. Worp in 1995. It contained 90 remains of papyrus texts in Greek, all from the House 1-3 complex. Genres include letters, memos, astrological calendars, contracts, and petitions. Two years later, Roger S. Bagnall published the Kellis Agricultural Account Book, a codex from House 2 of great importance for understanding the local economy. ${ }^{19}$ Coptic documentary material were edited by Iain Gardner, Anthony Alcock and Wolf-Peter Funk, and published in two instalments, P.Kellis $V$ (1999) and P.Kellis VII (2014). These two volumes contain 118 texts and fragments, mostly of private letters. All but ten stem from the House 1-3 complex. Texts written on ostraka from House $1-3$ were included in Worp's publication

18 Anna L. Boozer, 'Archaeology on Egypt's Edge: Archaeological Research in the Dakhleh Oasis, 1819-1977', Ancient West \& East 12 (2013).

19 Roger S. Bagnall, ed., The Kellis Agricultural Account Book (P.Kellis IV Gr. 96) (Oxford: Oxbow, 1997). 
O.Kellis I (2004). Additional material, mostly from other parts of Kellis, has appeared in various articles. ${ }^{20}$ Finally, the literary material from House 1-3 consists of a range of texts in Coptic, Greek, as well as fragments in Syriac. In 1991, it was realised that these included Manichaean literary remains. They were edited by Iain Gardner, with the assistance of several other scholars, and published in P.Kellis II (1996) and P.Kellis VI (2007). ${ }^{21}$ These volumes contain a total of 31 pieces. They include Biblical texts and magical texts, but also remains of Mani's Epistles, prayers of Manichaean extraction, as well as psalms that can be identified with counterparts in the Medinet Madi Psalm-book.

\section{Manichaean Social Organisation}

The amount of material relating to Manichaeism from the Roman Empire is today relatively substantial. ${ }^{22}$ Yet before the discoveries at Kellis, sources for

$20 \quad$ Klaas A. Worp, Greek Ostraka from Kellis. Vol. 1 (O.Kellis I, nos. 1-293) (Oxford: Oxbow, 2004); John F. Oates, 'Sale of a Donkey (P.Duke inv. G9)', The Bulletin of the American Society of Papyrologists 25 (1988); John F. Oates and Peter van Minnen, 'Three Duke University Papyri from Kellis', in Papyri in Memory of P. J. Sijpesteijn (P.Sijp.), ed. Klaas A. Worp and Adriaan J. B. Sirks (Oakville: The American Society of Papyrologists, 2007); T. de Jong and Klaas A. Worp, 'A Greek Horoscope from 373 AD', Zeitschrift für Papyrologie und Epigraphik 106 (1995); T. de Jong and Klaas A. Worp, 'More Greek Horoscopes from Kellis (Dakhleh Oasis)', Zeitschrift für Papyrologie und Epigraphik 137 (2001); Roger S. Bagnall and Klaas A. Worp, 'Two 4th Century Accounts from Kellis', in Papyri in honorem Johannis Bingen octogenarii (P.Bingen), ed. Henri Melaerts, Rudolf de Smet, and Cecilia Saerens (Leuven: Peeters, 2000); Colin A. Hope and Klaas A. Worp, 'A Greek Account on a Clay Tablet from the Dakhleh Oasis', in ibid.; Klaas A. Worp, 'A New Wooden Board from the Temple at Kellis (with plate XXVI)', in Akten des 21. Internationalen Papyrologenkongresses, Berlin, 13.-19.8 1995, ed. Bärbel Kramer, et al. (Stuttgart; Leipig B. G. Teubner, 1997); Klaas A. Worp, 'Short Texts from the Main Temple', in Dakhleh Oasis Project: Preliminary Reports on the 1994-1995 to 1998-1999 Field Seasons, ed. Colin A. Hope; Gillian E. Bowen (Oxford: Oxbow, 2002); Colin A. Hope and Klaas A. Worp, 'Dedication inscription from the Main Temple', in ibid.; Roger S. Bagnall, Colin A. Hope, and Klaas A. Worp, 'Family Papers from Second-Century A.D. Kellis', Chronique d'Égypte 86, no. 171-172 (2011); Klaas A. Worp, 'Miscellaneous New Greek Papyri from Kellis (P.Gascou 67-88)', in Mélanges Jean Gascou: Textes et études papyrologiques (P.Gascou), ed. Jean-Luc Fournet and Arietta Papaconstantinou (Paris: Collège de France, 2016).

21 There was also a codex of speeches by the classical Athenian rhetor Isocrates, published in Klaas A. Worp and Albert Rijksbaron, eds., The Kellis Isocrates Codex (P.Kellis III Gr. 95) (Oxford: Oxbow, 1997).

22 For an extensive selection, see Iain Gardner and Samuel N. C. Lieu, Manichaean Texts from the Roman Empire (Cambridge: Cambridge University Press, 2004). 
apprehending life and practice among the laity did not come from lay insiders themselves. Early scholars were dependent on the polemically shaped writings of Augustine and other anti-Manichaean texts, while the materials from Medinet Madi and Turfan seem largely to have been the product of Manichaean authorities. Much scholarship has, moreover, been preoccupied with editing the latter texts, most of which were badly damaged. When engaged with historical analysis, more attention has been paid to Mani and his role within the 'history of religions', i.e. his formative influences or his mythological system, than with the social practices of his later adherents. One feature that early scholars did stress, however, was the institutional 'primitiveness' of the movement. The Elect discipline, entailing an itinerant and ascetic life, was seen as ruling out features such as temples, altars, images, and organised ritual. ${ }^{23}$ Moreover, for most of the 2oth century, it was primarily seen as a type of 'Gnosticism', i.e. a spiritual faith focused on salvation through revealed knowledge. Manichaeism was therefore assumed to put little emphasis on or even rejected ritual practice, making institutional organisation less important. ${ }^{24}$ At the same time, this had to be reconciled with its many institutionalised features, such as its hierarchy of officials. With the discovery of Manichaean remains in the Turfan Basin, scholars were faced with evidence for a state-supported, Manichaean organisation in possession of 'monasteries', ritual proscriptions, strict regulations, and steady income. ${ }^{25}$

These two dimensions have continued to exist side-by-side in the scholarly literature. The concept of Gnosticism has been problematised, and its relevance for understanding Manichaeism has lessened, but the view that Roman Manichaeism was characterised by weak institutions remains influential. ${ }^{26}$ Most scholars agree that western Manichaeism followed a very different trajectory from that of the east, being nearer to the charismatic mode of life of the early movement than of the later organised Church in Turfan even leading to the claim that 'the Manichaeans [of the west] did not share

23 See Flügel, Mani, seine Lehre, 324-25; Ferdinand C. Baur, Das manichäischen Religionssystem nach den Quellen neu undersucht und entwickelt (Tübingen: S. F. Osiander, 1831), 351.

24 For a review and criticism of this approach, see BeDuhn, The Manichaean Body, 211-22.

25 For the Manichaean Central Asian texts, see Jes P. Asmussen, Manichaean Literature (New York: Scholars' Facsimilies \& Reprints, 1975); Werner Sundermann, Mitteliranische manichäische Texte kirchengeschichtlichen Inhalts (Berlin: Akademie Verlag, 1981); Tardieu, Manichaeism, 57-74; Claudia Leurini, The Manichaean Church: An Essay Mainly Based on the Texts from Central Asia (Rome: Scienze e lettere, 2013).

26 See Michael A. Williams, Rethinking “Gnosticism”: An Argument for Dismantling a Dubious Category (Princeton, NJ: Princeton University Press, 1996). 
the view with the Christians that the church should be an institution.'27 It has received support among scholars of Augustine and Latin North African Manichaeism, who, following the work of François Decret, have come to focus on local diversity within the movement. Decret argued that the Manichaean Church was rather distant to most adherents in North Africa, and indeed that Manichaeans in the Latin west largely rejected the type of clerical authority that Augustine later came to embrace as a Catholic. Instead, adherents exercised much local autonomy in organising the faith. ${ }^{28}$ Decret's views led to a spirited exchange with another prominent French scholar, Michel Tardieu, but several scholars have since taken its localised character as a starting point for investigating North African Manichaeism. ${ }^{29}$ Among the strongest proponents of this view is Richard Lim. In an article from 1989, he criticised the way scholars have uncritically reproduced 'a consistent and coherent social entity called "Manichaeism", together with its attendant system of ideas. ${ }^{30}$ He argued that the Elect disciplinary regime was non-conducive to an effective church institution, so that any such institution must have played little role in North Africa. The Elect are better conceived of along the lines of Gerd Theissen's 'wandering charismatics'; that is, itinerant religious virtuosi, whose authority was based on their individual qualities rather than on institutional affiliation. Instead of focusing on the Manichaean church organisation, scholars should pay attention to how Manichaean ideas and texts were appropriated by Christians. ${ }^{31}$ In a more recent article, he has similarly criticised scholars for taking a distinct 'Manichaean' group identity for granted, arguing that this identity was mainly adopted by elite Christians with an interest in philosophy.

27 Samuel N. C. Lieu, 'A Lapsed Manichaean's Correspondence with a Confucian Official in the Sung Dynasty (1264)', in Manichaeism in Central Asia and Medieval China (Leiden: Brill, 1998), 104.

28 François Decret, L'Afrique manichéenne: $I V^{e}-V^{e}$ siècles. Étude historique et doctrinale (Paris: Études augustiniennes, 1978), 267-68; id., 'Le manichéisme présentait-il en Afrique et à Rome des particularismes régionaux distinctifs?', Augustinianum 34, no. 1 (1994): $12 \mathrm{ff}$.

Michel Tardieu, 'Vues nouvelles sur le manichéisme africain?', Revue d'Etudes Augustiniennes et Patristiques 25, no. 3-4 (1979); François Decret, 'Encore le manichéisme', Revue d'Etudes Augustiniennes et Patristiques 26, no. 3-4 (1980). For studies following Decret, see Daniel McBride, 'Egyptian Manichaeism', Journal for the Society of the Study of Egyptian Antiquities 18 (1988), J. Kevin Coyle, 'Characteristics of Manichaeism in Roman Africa', in New Light on Manichaeism, ed. Jason D. BeDuhn (Leiden: Brill, 2009).

30 Richard Lim, 'Unity and Diversity among Western Manichaeans: A Reconsideration of Mani's sancta ecclesia', Revue d'Études Augustiniennes et Patristiques 35, no. 2 (1989): 232.

31 Ibid., 239-46. 
The arguments of Lim and other scholars who warn against taking the 'canonical' depiction for granted have brought a much-needed call for historical sensitivity to the field, in line with deconstructions of other heresiological categories and of a monolithic early Christian 'Church' or 'original community' ${ }^{22}$ But in spite of concerns for the Manichaean point of view, Lim's argument is primarily based on the writings of Augustine and other polemical sources. Nils A. Pedersen has recently objected that the Manichaean texts themselves give us little reason to think that western Manichaeans were primarily Christian intellectuals: preserved Manichaean texts are not philosophical treatises, but communal and ritual in character. ${ }^{33}$ Jason D. BeDuhn's reconstruction of the Elect meal, based on Manichaean sources, has shown a high degree of unity between eastern and western texts, in terms of norms and discourses that governed ritual practice. ${ }^{34}$ Still, these texts chiefly provide evidence for the discourse of Manichaean authorities. Lay adherents, such as Horos and Horion, may not have considered themselves to be participating in a distinct 'Manichaeism', despite attempts by authorities ('Manichaean' as well as 'Christian') to frame them in this light.

\section{1}

\section{'Manichaeism' and its Discontents}

In this context, the controversy surrounding the labels 'Manichaeism' and 'Manichaean', and their implications for Manichaean self-identity (or lack thereof), needs to be reviewed. As Nicholas Baker-Brian has put it, 'arguably the most problematic label in Manichaean studies continues to be the term "Manichaean" itself.'35 In one sense, discussion of how to label Manichaeism, and the consequences of labels for how the movement is to be understood, can be traced back to debates such as those between Augustine and the Manichaeans themselves. For Augustine and contemporary Christian leaders, Manichaeism originated as a hairesis of their own tradition, a dangerous and novel deviation from the true teachings of the Church, particularly abhorrent

32 E.g. Alain le Boulluec, La notion d'hérésie dans la littérature grecque II ${ }^{e}-I I I^{e}$ siècles (Paris: Études Augustiniennes, 1985). Williams, Rethinking “Gnosticism"; Eduard Iricinschi and Holger M. Zellentin, 'Making Selves and Marking Others: Identity and Late Antique Heresiologies', in Heresy and Identity in Late Antiquity, ed. E. Iricinschi and H. M. Zellentin (Tübeck: Mohr Siebeck, 2008); Stanley Stowers, "The Concept of "Community" and the History of Early Christianity', Method and Theory in the Study of Religion 23 (2011).

33 Nils A. Pedersen, 'Manichaean Self-Designations in the Western Tradition', in Augustine and Manichaean Christianity, ed. Johannes van Oort (Leiden: Brill), 177-98.

34 BeDuhn, The Manichaean Body.

35 Baker-Brian, Manichaeism, 23. 
for its dualism. ${ }^{36}$ Medieval Christian authorities perpetuated this view, employing the term 'Manichaean' to vilify dualists and other 'heretics' of their time.

Modern scholarly usage of the term is rooted in the religious polemics of early modern Europe. The Huguenot Isaac de Beausobre (1659-1738) is often regarded as the first modern scholar of Manichaeism. ${ }^{37}$ In his view, Manichaeans and their presumed successors, the Cathars and the Valdensians, were 'heretical' in a more positive sense: they could in some ways be considered proto-Protestants; groups representing an early strand of Christianity that had been in opposition to - and in turn been vilified by - the Catholic Church, much like the French Huguenots themselves. ${ }^{38}$ With the expansion of the study of religion, more attention was bestowed upon other formative influences. Ferdinand C. Baur argued that Iranian and Indian traditions were particularly important for Mani. ${ }^{39}$ The translation of works by Muslim scholars touching on Manichaeism brought the Mesopotamian background to the fore, drawn attention to by Konrad Kessler. ${ }^{40}$ The early 2oth-century discovery of Iranian, Chinese, and Turkic Manichaean texts in Turfan strengthened the quest for origins outside the Christian sphere. Richard Reitzenstein saw the Iranian Manichaean texts as a 'missing link', evidence for a Mazdayasnian origins of Hellenistic mystery religions, Christianity, as well as Gnosticism including Manichaeism. ${ }^{41}$ This understanding came to dominate the study of Manichaeism for much of the 2oth century. When Coptic Manichaean texts

36 For Roman anti-Manichaean discourse, see Samuel N. C. Lieu, 'Some Themes in Later Roman Anti-Manichaean Polemics: I', Bulletin of the John Rylands University Library 68, no. 2 (1986); id., 'Some Themes in Later Roman Anti-Manichaean Polemics: II', Bulletin of the John Rylands Library 69, no. 1 (1986); Sarah Stroumsa and Guy G. Stroumsa, 'Aspects of Anti-Manichaean Polemics in Late Antiquity and under Early Islam', Harvard Theological Review 81, no. o1 (1988); Neil Adkin, 'Heretics and Manichees', Orpheus 14 (1993). For later anti-Manichaean polemics by Jews and Muslims, see John C. Reeves, 'A Manichaean "Blood Libel"?', ARAM 16 (2004).

37 Johannes van Oort 'Würdigung Isaac de Beausobres (1659-1738)', in Studia Manichaica IV. Proceedings of the IVth International Conference of Manichaean Studies, Berlin, 14.-18. Juli 1997, ed. Ronald E. Emmerick, Werner Sundermann and Peter Zieme (Berlin: Akademie Verlag 200o); Guy G. Stroumsa, 'Isaac de Beausobre Revisited: The Birth of Manichaean Studies', in ibid.; and also id., A New Science: The Discovery of Religion in the Age of Reason (Cambridge: Harvard University Press, 2010), 113-23.

38 Stroumsa, 'Isaac de Beausobre', 604-11.

39 Baur, Das manichäischen Religionssystem, 416ff; Stroumsa, A New Science, 123.

40 Konrad Kessler, Mani. Forschungen über die manichäische Religion (Berlin: Georg Reimer, 1976).

41 See Karen L. King, What is Gnosticism? (Cambridge, Mass.: Belknap Press of Harvard University Press, 2003), 84-9o; Iain Gardner and Samuel N. C. Lieu, 'From Narmouthis (Medinet Madi) to Kellis (Ismant el-Kharab): Manichaean Documents from Roman Egypt', The Journal of Roman Studies 86 (1996): 147-48. 
found at Medinet Madi in Egypt were published in the 1930s, they furnished evidence which, amongst others, led scholars to examine the connection between Manichaeism and Mandaeism more closely. ${ }^{42}$

Still, the Christian connection was never neglected. Francis C. Burkitt used another newly-recovered source, the anti-Manichaean writings of the fourth-century Christian leader Ephrem of Edessa, to argue for a Christian background.$^{43}$ Ephrem quoted Manichaean writings in Mani's own language, Syriac, making his testimony particularly valuable. Reitzenstein was also criticised by one of his own students, Hans Schaeder, who drew on a treatise by the late-third century philosopher Alexander of Lycopolis to argue the essentially Hellenistic-Christian nature of the movement. The importance of Christianity to Mani's formative years and the movement at large, in line with Burkitt's approach, is generally accepted today. The discovery of Christian gnostic texts in Nag Hammadi in 1945 brought insight into the diversity of early Christian traditions, and the Cologne Mani Codex that appeared in 1969 shed new light on Mani's self-conception and life, attesting to his youth among the 'Elchasaite' Jewish-Christian baptists. This has led to valuable studies of, for instance, Manichaean Bible exegesis and the writings of Christian heresiologists. ${ }^{44}$ It has also led to increased scrutiny of the term 'Manichaeism'. In preserved literary sources, 'Manichaean' is only rarely found as a label of self-identity. While Ephrem claimed that Mani had bestowed his name on the movement, this is often rejected by scholars. ${ }^{45}$ Following up on his analysis of Manichaean organisation, Lim has been one of the most forceful critics of the usage of this term. In an article from 2008, he has argued that it obscures our understanding of the movement. As his starting point, he takes one of the few attested instances of 'Manichaean' used as an autonym, found in a letter to Augustine

42 Geo Widengren, Mesopotamian Elements in Manichaeism (Uppsala: Lundequistska bokhandeln, 1946); Torgny Säve-Söderbergh, Studies in the Coptic Manichaean Psalm-Book: Prosody and Mandaean Parallels (Uppsala: Almqvist \& Wiksell, 1949).

43 Francis C. Burkitt, The Religion of the Manichees (Cambridge: Cambridge University Press, 1925); Gardner and Lieu, 'From Narmouthis', 147-48; for Ephrem's sources, John C. Reeves, 'Manichaean Citations from the Prose Refutations of Ephrem', in Emerging from Darkness, ed. Paul Mirecki and Jason D. BeDuhn (Leiden: Brill, 1997).

44 Nils A. Pedersen, Demonstrative Proof in Defence of God: A Study of Titus of Bostra's Contra Manichaeos (Leiden: Brill, 2004); Jason D. BeDuhn and Paul A. Mirecki, eds., Frontiers of Faith: The Christian Encounter with Manichaeism in the Acts of Archelaus (Leiden: Brill, 2007); Jacob A. van den Berg, Biblical Argument in Manichaean Missionary Practice: The Case of Adimantus and Augustine (Boston: Brill, 20o9); Alexander Böhlig, Peter Nagel, and Siegfried Richter, Die Bibel bei den Manichäern und verwandte Studien (Leiden: Brill, 2013).

45 So, for instance J. Kevin Coyle, 'Foreign and Insane: Labelling Manichaeism in the Roman Empire', Studies in Religion / Sciences Religieuses 33, no. 2 (2004): 218. 
by a certain Secundinus. In Lim's view, Secundinus should not be seen as a Manichaean, per se, but is better understood as 'a philosophically inclined Christian who has chosen to follow the superior teachings of Mani'46 By using 'Manichaeism', scholars have been reproducing a label created by mainstream Christian authorities: 'we owe the sense of a distinctive Manichaean identity to the works of catholic/orthodox Christian writers who ... sought to invent the image of an alien Other so as to be able to condemn more efficaciously the specific practices, beliefs and persons. ${ }^{47}$ Thus, scholars wrongly construe Manichaeism as a separate religion, obscuring the fact that for most believers it was just 'another - indeed more rigorist - way to follow Christ's teachings.' ${ }^{4}$ Others have made similar assessments. Baker-Brian has argued that the term obscures the formative influences on Mani (i.e. his Judaeo-Christian background) and perpetuates the 'assumption that Mani's teachings appeared fully formed, systematised and institutionally-implemented from the very earliest days'49 This critique of 'Manichaeism' has led to attempts to discard the term. It is now frequently argued that it is better simply to subsume Manichaeism under the more general category 'Christianity'. ${ }^{50}$ Baker-Brian, while deciding to retain the term in his book, ends his survey of the debate by stating that 'Manichaeism' might be better conceived of as a form of ancient Mesopotamian Christianity. ${ }^{51}$ Alexander Khosroyev has suggested that a description such as 'the high-mythologised syncretistic dualistic Christianity of Mani' might make more sense than 'Manichaeism. ${ }^{52}$

46 Richard Lim, 'The nomen manichaeorum and its Uses in Late Antiquity', in Heresy and Identity in Late Antiquity, ed. Eduard Iricinschi and Holger M. Zellentin (Tübingen: Mohr Siebeck, 2008), 16o.

47 Ibid., 147.

48 Ibid., 164.

49 Baker-Brian, Manichaeism, 23.

50 See Pedersen, Demonstrative Proof, 8; Peter van Minnen, review of Documentary Letters from the Middle East, by Eva Mira Grob and Andreas Kaplony, eds., Bulletin of the American Society of Papyrologists 46 (2009); Iain Gardner, 'Towards an Understanding of Mani's Religious Development and the Archaeology of Manichaean Identity', in Religion and Retributive Logic: Essays in Honour of Professor Garry W. Trompf, ed. Carole Cusack and Christopher Hartney (Boston: Brill, 2010).

51 Baker-Brian, Manichaeism, 24.

$5^{2}$ 'Also kann man diese religiöse Bewegung als "das hochmythologisiert-synkretistische dualistische Christentum des Mani” bezeichnen. In solcher Definition scheint mehr Sinn zu sein als im Terminus "Manichäismus". Alexander Khosroyev, 'Manichäismus: eine Art persisches Christentum?', in Inkulturation des Christentums im Sasanidenreich, ed. Arafa Mustafa, Jürgen Tubach, and G. Sophia Vashalomidze (Wiesbaden: Reichert Verlag, 2007), 51 . 
However, there are to my mind good reasons to keep the label 'Manichaeaism', and to maintain a distinction between it and 'Christianity'. Certainly, scholars should not uncritically adopt heresiological labels or reify phenomena that their research subjects would not have recognised. ${ }^{53}$ On the other hand, the history of the term 'Manichaean' is not as clear-cut as it has been made out to be. Heresiologists certainly preferred this label, perhaps to emphasise the foreignness of the movement, ${ }^{54}$ and it is not frequently found in our sources but it is found: the corpus includes two instances of 'Manichaean' used as a self-designation, ${ }^{55}$ and its usage was promoted by the authors of the Berlin Kephalaia, who (in agreement with Ephrem) attributed it to Mani. ${ }^{56}$ It may be that the term was reserved for specific contexts, perhaps for particular instances of outside identification, as argued by Pedersen. ${ }^{57}$ Conversely, the term 'Christian' is not widely used among Manichaeans as a self-designation either. While some of Augustine's interlocutors employ it, claiming for themselves 'true' Christianity, it is not found in the letters of Kellis, as Baker-Brian and Pedersen have both pointed out. ${ }^{58}$

More importantly, I am not convinced that scholarly usage of the term 'Manichaeism' as an etic label causes unreasonable distortion. For one, other suggested labels do not seem suitable either. Labels such as 'Mesopotamian

53 See Walter Bauer, Orthodoxy and Heresy in Earliest Christianity, trans. Robert A. Kraft and Gerhard Krodel (Philadelphia: Fortress Press, 1971); Boulluec, La notion d'hérésie; Iricinschi and Zellentin, 'Making Selves'.

54 See for instance Coyle, 'Foreign and Insane', 218; Lim, 'nomen manichaeorum', 149.

55 By Secundinus, and on the gravestone of a certain Bassa, 'Manichaean', found near Salona. For the latter, see Madeleine Scopello, Femme, gnose et manichéisme: de l'espace mythique au territoire du réel (Leiden: Brill, 2005), 293-315. The term can likely be restored in keph. 115 (1 Ke. 271.15), albeit see the cautionary note (based on the few other occurrences) of Iain Gardner, The Kephalaia of the Teacher: The Edited Coptic Manichaean Texts in Translation with Commentary (Leiden: Brill, 1995), 278 n.146.

56 In keph. 105, Mani is made to explain why (or in which instances) certain people use the name of 'Christ' to label themselves. Subsequently, he asserts: 'by my good and useful teachings that I have revealed; see, people who love me are called of my name!' (1 Ke. 259.13). A conceptual distinction between 'Christian' and 'Manichaean', and a promotion of a label based on Mani's name, is implied, as noted by Alexander Böhlig, 'Christliche Wurzeln in Manichäismus', in Mysterion und Wahrheit: Gesammelte Beiträge zur spätantiken Religionsgeschichte (Leiden: Brill, 1968), 204-5. Pedersen has cautioned against generalising based on a single passage, but also suggested (in line with recent arguments by Gardner) that the Kephalaia 'represents an attempt to dissociate Manichaeism from Christianity'. Pedersen, 'Manichaean Self-Designations', 191. If so, this development was likely taking place already towards the end of the third century, in the Syro-Mesopotamian sphere; see Chapter 9, Section 4, n.115.

57 Pedersen, 'Manichaean Self-Designations'.

$5^{8}$ Baker-Brian, Manichaeism, 17; Pedersen, 'Manichaean Self-Designations', 188-89. 
Christianity' do not capture the distinctiveness of the beliefs, practices, or self-understanding of the movement. 'Manichaean Christianity' has been suggested as another replacement. However, the category of 'Christianity' itself should not be taken for granted, and is problematic in this context. It entails a modern typology that subsumes 'Manichaeism' under 'Christianity', in turn contrasting it to 'Buddhism' or 'Mazdayasna'. This would have been foreign to Mani, who considered his Church just as much heir to the 'Churches' of Buddha and Zarathustra as to that of Paul or Christ, and equally opposed to their later incarnations.

Secondly, the term 'Manichaeism' does not in itself obscure the formative Christian influences on Mani, at least no more or less than the term 'Christian' obscures the Jewish context of early Christianity.59 Conversely, exchanging 'Manichaean' for 'Christian' obscures other, central influences and historical developments that contributed to the movement's characteristics. Mani may have started out as an enthusiastic ('Elchasaite') Christian, and the narratives of Jesus and his disciples, the epistles of Paul, Biblical exegesis, and Christian symbols all remained important to his followers. However, by the end of his 35 years of activity, the movement had integrated ideas such as the salvific role of the Elect, the suffering world soul, reincarnation, the periodic incarnation of 'Apostles of Light' (including Zarathustra and Buddha), and divine roles for the sun and the moon, as well as practices such as daily ritual meals and weekly confession; features consciously adapted from Iranian (Mazdayasnian), Indian (Buddhist, Jain), or other traditions, or internal developments. ${ }^{60} \mathrm{I}$ do

59 This has admittedly led scholars to discard the term 'Christianity' for the earliest groups, preferring terms such as 'Jesus movement' or 'Christ groups'. However, as we shall see in the course of the present study, the 'Church' of Mani emerged in a very different context, and with a very different starting point, from that of the early Jesus movement.

6o For the Indian (particularly Jain) background of Manichaean teachings on 'reincarnation' ( $\mu \varepsilon \tau \alpha \gamma / \sigma \mu o ́ s)$, see Albert Henrichs, “Thou Shalt Not Kill a Tree": Greek, Manichean and Indian Tales', The Bulletin of the American Society of Papyrologists 16, no. 1-2 (1979): 106; also Iain Gardner, 'Some Comments on Mani and Indian Religions: According to the Coptic Kephalaia', in Il Manicheismo. Nuove prospettive della ricera, ed. A. van Tongerloo and L. Cirillo (Turnhout: Brepols, 2005); and Max Deeg and Iain Gardner, 'Indian Influence on Mani Reconsidered: The Case of Jainism', International Journal of Jaina Studies 5, no. 2 (2009). For the Indian roots of the confession ritual, see Jason D. BeDuhn, 'The Near Eastern Connections of Manichaean Confessionary Practice', ARAM 16 (2004); id., 'The Manichaean Weekly Confession Ritual', in Practicing Gnosis: Ritual, Magic, Theurgy and Liturgy in Nag Hammadi, Manichaean and other ancient literature, ed. April D. DeConick, Gregory Shaw, and John D. Turner (Leiden: Brill, 2013), 274-75; and for the Mazdayasnan affinities of the ritual meal, id., 'Eucharist or Yasna? Antecedents of Manichaean Food Ritual', in Studia Manichaica: Proceedings of the IVth International Conference of Manichaean Studies, Berlin 1997, ed. Ronald E. Emmerick, Werner Sundermann, and 
not think that these were external trappings, as is sometimes argued; ${ }^{61}$ rather, they were part and parcel of its core ideas and practices - elements which, as P. Oktor Skjærvø has put it, were 'melted into an alloy in which the constituent elements are no longer separately identifiable. ${ }^{62}$ Mani's religious authority was an important ingredient in this alloy, and therefore became a contentious issue. Manichaeans in the west had to convince potential Christian converts that their scriptures should be read through the lens of Mani's tradition. It is no wonder that the virtues of Mani, the authenticity of his revelations, and the validity of his scriptural exegesis played a major role in Christian polemics. ${ }^{63}$

This brings us to the question of whether it makes sense to think of Manichaeism as a separate 'religion' - a term that has itself received much scholarly scrutiny. ${ }^{64}$ Yet, even its critics have tended to apply it to Manichaeism. Wilfred C. Smith, who famously initiated the deconstruction of 'religion' as an essentialist concept, still located something approximating it in Islam, and noted Manichaeism as a forerunner. ${ }^{65}$ Jonathan Z. Smith, in his criticism of the category 'world religion', pointed out as a fault that 'no typology includes Manichaeism, perhaps the first, self-conscious "world" religion.'66 Recent takes have been less certain. As we saw, Lim rejected 'Manichaeism' as a 'Catholic' construct. A study by Brent Nongbri of the term 'religion' has also rejected the case for classifying Manichaeism as such. In line with Lim, he argues that since Mani and his disciples operated with a self-understanding as Christian,

Peter Zieme (Berlin: Akademie Verlag, 200o). For shared texts and myths, see Dilley, 'Also schrieb Zarathustra? Mani as Interpreter of the "Law of Zarades"'; and Jason D. BeDuhn, 'Iranian Epic in the Chester Beatty Kephalaia', in Mani at the Court of the Persian Kings, ed. Iain Gardner, Jason D. BeDuhn, and Paul Dilley (Leiden: Brill, 2015).

61 E.g. Burkitt, Religion of the Manichees, 14, 41-42, 73-79. Similarly, Lieu has maintained that 'the Zoroastrian and Buddhist elements were acquired in the course of mission and were not fundamental to Manichaeism'. Lieu, Manichaeism in the Roman Empire, 53-54. See also Gardner, 'Mani's Religious Development', 156.

62 Skjærvø (1995), cited in Timothy Pettipiece, 'A Church to Surpass All Churches: Manichaeism as a Test Case for the Theory of Reception', La théorie de la réception 61, no. 2 (2015): 254 .

63 On the role of Mani's authority in Augustine's debates, see Eduard Iricinschi, 'Tam pretiosi codices uestri: Hebrew Scriptures versus Persian Books in Augustine's Anti-Manichaean Writings', in Revelation, Literature, and Community in Late Antiquity, ed. Philippa Townsend and Moulie Vidas (Tübingen: Mohr Siebeck, 2011), 168ff.

64 E.g. Jonathan Z. Smith, 'Religion, Religions, Religious', in Critical Terms for Religious Studies, ed. Mark Taylor (Chicago: University of Chicago Press, 1998); Brent Nongbri, Before Religion: A History of a Modern Concept (New Haven: Yale University Press, 2013).

65 Wilfred C. Smith, The Meaning and End of Religion: A New Approach to the Religious Traditions of Mankind (New York: Macmillan, 1963), 98-105.

66 Jonathan Z. Smith, 'Taxonomies of Religion', Harvard Theological Review 89, no. 4 (1996): 396. 
the movement is better understood in terms of the (Christian) dynamics between 'orthodoxy' and 'heresy'. Later Manichaeans, too, lacked a distinctive religious identity, inferred from the ease with which they adapted to new cultural contexts. ${ }^{67}$

Yet, while certain aspects were accommodated to local languages and conceptual frameworks, recent finds increasingly point to cross-temporal coherence, as we shall see. Furthermore, rather than reducing Manichaeism to a product of Christian heresiology, there are good reasons to see it as the result of the Manichaeans' own conceptual work - not least since Mani's usage of the term ekklesia, 'church', in many ways approximates the modern notion of religion. Indeed, Hans-Jakob Polotsky translated it as 'religion' in certain chapters of the Berlin Kephalaia, a move criticised by Pedersen due to the term's modern connotations. ${ }^{68}$ Yet, it can equally be objected that the Manichaean concept of 'church' does not correspond to the modern one, either. 'Church', today, implies a subset of the genus 'Christianity', a family of groups that in turn is contrasted to 'Islam' or 'Buddhism'. As pointed out above, this is not how Mani or his disciples used this term: they included 'Churches' of Zarathustra, Buddha, and other sages alongside that of Jesus, all part of the same family of groups. This point has recently been made by BeDuhn. ${ }^{69}$ He points out that Mani saw his Church as involving a social community, beliefs, and practices. By contrasting it with (i.e. construing) other 'Churches' on the same model, he created a categorisational scheme very much like that implicit in the modern category 'religion':70 In fact, it may well constitute the first - known and coherent attempt at delineating such a scheme. There is, then, no contradiction between

\footnotetext{
67 Nongbri, Before Religion, 66-73.

68 Pedersen, Demonstrative Proof, 8 n.13.

69 Jason D. BeDuhn, 'Mani and the Crystallization of the Concept of "Religion" in Third-Century Iran', in Mani at the Court of the Persian Kings, ed. Iain Gardner, Jason D. BeDuhn, and Paul Dilley (Leiden: Brill, 2015).

70 Nongbri maintains that Manichaean usage of ekklesia denoted 'social groups, not disembodied "religious" systems' (Before Religion, 70), citing an important chapter of the Berlin Kephalaia, keph. 151. However, this ignores both the social aspect of the modern term, and the abstract 'ideological' component of Mani's usage. The latter is evident in keph. 151 itself, where faith, practice, and group are mixed. So, for instance, one passage reads: 'Blessed is the person who will trust in it(i.e. the Church) and agree with it and remain in it; and he will profit and live in its life and [...] in its primacy. And he will go up and be at rest in the aeon of light' (1 Ke. 375.2-6, trans. Gardner and Lieu, Manichaean Texts, 267). See also Reinhold Glei and Stefan Reichmuth, 'Religion between Last Judgement, Law and Faith: Koranic din and Its Rendering in Latin Translations of the Koran', Religion 42, no. 2 (2012): 257-6o; and David Frankfurter, review of Before Religion by Brent Nongbri, Journal of Early Christian Studies 23, no. 4 (2015): 634 .
} 
taking Manichaeans to be strongly Christian, on the one hand, and at the same time belonging to a separate entity from that of 'Christianity', i.e. 'Manichaeism', on the other.

\subsection{Laity and Lived Religion}

Yet, even if Manichaeism was seen as a distinct 'religion' by Mani and other Elect leaders, the way it was conceived of among the Auditors, on the level of everyday religious practice and identity, needs closer scrutiny. As we saw above, scholars of Manichaeism in Latin North Africa have argued that Manichaean church authorities only played a minor role in this region. Lim, moreover, suggested that most Manichaeans so-called did not possess a distinctly Manichaean self-identity. A similar, if less strong, claim has been made by scholars for the laity at Kellis. The papyri from House 1-3 have been taken to show that most lay believers did not consider themselves part of a community with practices or beliefs very different from those of other Christians. As Iain Gardner wrote in the first publication of literary texts from Kellis, contrasting the Auditors to the Elect, " $\mathrm{t}$ ] he concerns of the mass of believers were necessarily more matter-of-fact, for whom Manichaeism would have been a kind of higher and more effective Christianity. ${ }^{71}$ While the Elect interpreted a specialised literature composed by Mani and his disciples, lay adherents at Kellis may have been unfamiliar with the distinct ideas and practices of the movement. Either the Elect withheld parts of Mani's teachings from the laity, or the laity had little interest in such teachings. Approaches current in the 'lived religion' turn can be used to support this view. Instead of cohesive groups or shared identities, they focus on individual lay identities, which are argued to be situationally dependent and often at odds with religious authorities. ${ }^{72}$ Boundaries between different groups were largely the constructs of religious elites, and had few social ramifications beyond for those authorities that promoted them. Religious identity may, in general, have had little salience among lay people, as argued by Eric Rebillard for North African Christianity, and for the Kellis community by Mattias Brand. ${ }^{73}$

\footnotetext{
$71 \quad$ P.Kellis II, $\mathrm{ix}-\mathrm{x}$.

72 This perspective emerged from cultural and ethnographic studies, primarily those concerned with popular religion; see David D. Hall, ed., Lived Religion in America: Toward a History of Practice (Princeton, NJ: Princeton University Press, 1997); Meredith McGuire, Lived Religion: Faith and Practice in Everyday Life (Oxford: Oxford University Press, 2008).

73 See Eric Rebillard, Christians and Their Many Identities in Late Antiquity: North Africa, 200-450 CE (Ithaca: Cornell University Press, 2012); Mattias Brand, 'The Manichaeans of Kellis: Religion, Community, and Everyday Life' (Ph.D., University of Leiden, 2019).
} 


\subsection{The Study's Aim}

The present contribution argues, however, that the papyri from Kellis evince a more organised and self-conscious Manichaean community than previous scholarship has allowed for. It does so by engaging with the breadth of textual materials from Kellis, combining a study of the papyri with one of Manichaean social institutions. The last few years have seen the publication of important bodies of texts that have added substantially to our knowledge of both social and religious life in Kellis. These finds have increasingly begun to receive attention from scholars of Manichaeism. ${ }^{74}$ Yet none have grappled systematically with the relationship between the documentary and the literary papyri, the social life as well as the religious practice of the Manichaean families at Kellis. Only a few years ago, it could still be maintained that:

Despite recent attempts (in particular BeDuhn 200o) to reconstruct the practices that identified the Manichaeans, for the historian Manichaeanism remains mainly a body of doctrines, and our sources provide no evidence about the individuals who recognised themselves as members of this sect. ${ }^{75}$

74 Studies include Nikolaos Gonis and Cecilia Römer, 'Ein Lobgesang an den Vater der Grösse in P. Kellis II 94', Zeitschrift für Papyrologie und Epigraphik 120 (1998); Jean-Daniel Dubois, 'Une lettre manichéenne de Kellis (P. Kell. Copt. 18)', in Early Christian Voices: In Texts, Traditions, and Symbols, ed. David H. Warren, et al. (Boston: Brill, 2003); Jason D. BeDuhn, 'The Domestic Setting of Manichaean Cultic Associations in Roman Late Antiquity', Archiv für Religionsgeschichte 10 (2008); Iain Gardner, 'Manichaean Ritual Practice at Ancient Kellis: A New Understanding of the Meaning and Function of the So-Called Prayer of the Emanations', in In Search of Truth: Augustine, Manichaeism and Other Gnosticism. Studies for Johannes van Oort at Sixty, ed. Jacob A. van den Berg, et al. (Leiden: Brill, 2011); Majella Franzmann, 'Augustine's View of Manichaean Almsgiving and Almsgiving by the Manichaean Community at Kellis', 69, no. 1 (2013); Mattias Brand, 'Speech Patterns as Indicators of Religious Identities: The Manichaean Community in Late Antique Egypt', in Sinews of Empire: Networks in the Roman Near East and Beyond, ed. Eivind H. Seland and Håkon F. Teigen (Oxford: Oxbow, 2017); Nicholas J. Baker-Brian, 'Mass and Elite in Late Antique Religion: The Case of Manichaeism', in Mass and Elite in the Greek and Roman Worlds: From Sparta to Late Antiquity, ed. Richard Evans (London: Routledge, 2017); and Håkon Fiane Teigen, 'Limbs of the Light Mind: The Social World of a Manichaean Community' (Ph.D., University of Bergen, 2018).

75 Eric Rebillard, 'Late Antique Limits of Christianness: North Africa in the Age of Augustine', in Group Identity and Religious Individuality in Late Antiquity, ed. Eric Rebillard and Jörg Rüpke (Washington, DC: The Catholic University of America Press, 2015), 63-64. 
As we shall see, the Kellis papyri provide abundant evidence for Manichaean individuals and the lives they led. In order for these individuals to speak to us, however, we need to get to know them. The papyri are not only important for understanding Manichaeism: they provide a wealth of information concerning mundane life in a fourth-century Oasis village. The people who owned them could take this setting for granted, but we cannot, and without a proper appraisal of the context we run the risk of misinterpreting them. One aim of this study is therefore to investigate the owners of the papyri and their social environments. Using prosopography and network analysis, it seeks to identify central actors of the papyri, as well as their friends, neighbours, and business associates, and the familial, political, and economic relationships in which they were embedded. The extent and character of this network has important ramifications for how we understand the community at Kellis.

Our chief purpose, however, is to engage with the practices evinced by both the documentary and the literary material, and their implications for the organisation of Manichaean communities and the reproduction of Manichaean identity. We examine the social composition of the community, religious expressions used by the laity in their letters, practices linked to text, and patterns of interaction between laity and Elect and among the Elect themselves. While the Kellis material remains at the centre of attention, its Manichaean affinities (or lack thereof) have to be considered in light of other evidence, in particular the near-contemporary writings of Augustine and the codices from Medinet Madi. It is argued that we find a laity who consciously appropriated Manichaean traditions, Elect who actively engaged with the community, and institutionalised patterns of Elect - lay interaction. Finally, the contribution aims to show how our understanding of Manichaeism at Kellis in its turn has consequences for how we view the shift in 'religion' from antiquity to late antiquity. ${ }^{76}$ It is argued that the practices of lay adherents at Kellis show that this transition was not confined to the level of religious elites; rather, it involved widespread appropriation of new practices and modes of self-identification.

${ }_{7} 6$ For some modern takes on this shift, see John North, "The Development of Religious Pluralism', in The Jews among Pagans and Christians, ed. John North. Judith Lieu, and Tessa Rajak (London: Routledge, 1992), 174-93; Daniel Boyarin, Border Lines: The Partition of Judaeo-Christianity (Philadelphia: University of Pennsylvania Press); Guy G. Stroumsa, The End of Sacrifice: Religious Transformations in Late Antiquity (Chicago: University of Chicago Press, 2009). 


\subsection{Social Networks}

In order to accomplish these aims, we need theoretical tools that help us approach everyday religious practice. Specific concepts are introduced more thoroughly in the chapters where they occur; the present discussion provides an overview over the frameworks on which the present study draws. One is the broad tradition of symbolic interactionism, which furnishes us with concepts for apprehending how practice shapes and communicates religious identity. We return to it below. The other is that of social network theory. It provides concepts for apprehending the relationships between people - the social structures - that framed religious practices. Social structure is a malleable concept, however, encompassing various ways of approaching human interaction. Several intellectual strands of the late 2oth century employed the concept of social networks in order to escape what was seen as overly rigid concepts of earlier structuralists. ${ }^{77}$ Modern sociology have followed this trend, emphasising the dynamical ways in which power is asserted, information spread, and identities are constituted through webs of interpersonal relations.

One important sub-field is that of social network analysis (SNA). ${ }^{78}$ It provides tools for mapping large quantities of data in terms of networks of interpersonal relations, and for analysing individual authority and positions within these networks. Briefly stated, sNA defines networks as consisting of nodes (e.g. people) and ties (e.g. friendship), the total number of which forms a network structure. ${ }^{79}$ How resources or information spread ('flow') is analysed in terms of this structure, i.e. the number, directionality, and strength of ties, using concepts such as density, degree, and betweenness centrality. A rough division has emerged between formal and heuristic analysis. ${ }^{80}$ Formal analysis consists in the application of statistical tools to quantify concepts such as density and centrality, useful for evaluating the centrality of a given actor within a network

77 See e.g. the philosophical polemic of Gilles Deleuze and Felix Guattari. Prominent network-oriented theories are the actor-network theory (ANT) of Bruno Latour, and the works of Manuel Castell and of Michael Mann.

78 This field brought together various intellectual strands, including graph theory, sociometry, anthropology, and micro-sociology. Stephen P. Borgatti, et al., 'Network analysis in the Social Sciences', Science 323, no. 5916 (2009).

79 For basic definitions of these and other concepts, see Stanely Wasserman and Katherine Faust, Social Network Analysis: Methods and Applications (Cambrdige: Cambridge University Press, 1994), 17-21.

8o See Håkon F. Teigen and Eivind H. Seland, 'Introduction', in Sinews of Empire: Networks in the Roman Near East and Beyond, ed. Håkon F. Teigen and Eivind H. Seland (Oxford: Oxbow, 2017). 
and the structures of different networks. Several studies have applied statistical analysis to historical material. ${ }^{81}$ For the ancient world, Elizabeth A. Clark applied concepts of network density and distance to the literary sources relating to the late-fourth century Origenist controversy, arguing that the social networks of the participants were more important for the outcome than were theological niceties. ${ }^{82}$ While Clark examined literary letters, Giovanni Ruffini has applied the method to papyrological material, in his study on village and city elites in the papyri from late antique Aphrodito and Oxyrhynchus. ${ }^{83}$

Although useful for mapping social relations, the formal approach is limited by its dependence on quantitative material. But network theory also provides flexible heuristic models for interpreting social formations. The sociology of ancient religious movements has grown vast since the important contributions of Gerd Theissen and Wayne A. Meeks on early Christianity in the 1970s and $8{ }^{\circ},{ }^{84}$ and networks have become a standard part of the repertoire. Researchers often draw on concepts such as Mark Granovetter's 'the strength of weak ties' in order to explain patterns in the sources. ${ }^{85}$ The sociologist Rodney Stark argued that the primary vehicle for the dissemination of Christianity were ties of friends and family, 'conversion' primarily involving conforming one's beliefs to those of one's social peers and intimates. ${ }^{86}$ More recently, scholars such as Irad Malkin and Anna Collar have drawn on complexity theory, using concepts such as preferential attachment and information cascades to explain cultural dissemination within ancient social networks. ${ }^{87}$

81 See in particular the study of the political strategy of the Medicis, by Christopher K. Ansell and John Padgett, 'Robust Action and the Rise of the Medici, 1400-1434', American Journal of Sociology 98, no. 6 (1993).

82 Elizabeth A. Clark, 'Elite Networks and Heresy Accusations: Towards a Social Description of the Origenist Controversy', Semeia 56 (1992).

83 Giovanni Ruffini, Social Networks in Byzantine Egypt (Cambridge: Cambridge University Press, 2008).

84 Gerd Theissen, Sociology of Early Palestinian Christianity, trans. John Bowden (Philadelphia: Fortress Press, 1978); Wayne A. Meeks, The First Urban Christians: The Social World of the Apostle Paul (New Haven: Yale University Press, 1983).

85 An argument for the importance of peripheral ('weak') contacts. Mark Granovetter, 'The strength of weak ties', American Journal of Sociology 78, no. 6 (1973); id., 'The strength of weak ties: a network theory revisited', Sociological Theory 1 (1983). For surveys of such approaches, see Greg Woolf, 'Only Connect? Network Analysis and Religious Change in the Roman World', Hélade 2, no. 2 (2016); and Ruffini, Social Networks, 14-19.

86 Rodney Stark, The Rise of Christianity: A Sociologist Reconsiders History (Princeton, NJ: Princeton University Press, 1996).

87 Irad Malkin, A Small Greek World: Networks in the Ancient Mediterranean (New York: Oxford University Press, 2011); Anna Collar, Religious Networks in the Roman Empire: The Spread of New Ideas (New York: Cambridge University Press, 2013). 
At the same time, there is a risk of overestimating the explanatory force of network theoretical concepts. While social networks facilitate and affect the spread of religious ideas and practices, the latter cannot simply be reduced to 'content' that flows effortlessly through networks. As Greg Woolf has pointed out, in tracing the spread of religion we need to take account of how it, in turn, affects social relations through 'socialisation into new groups, apprenticeships in worship, the observance of new rules of behaviour, the acquisition of new habits. ${ }^{\prime 8}$ Cultural notions actively influence patterns of behaviour, in turn affecting the way networks develop. ${ }^{89}$

\subsection{Institution and Identity}

This brings us to the other theoretical tradition that this study draws on, namely the broad field of symbolic interactionism. It provides a range of concepts that can be used in order to analyse the relationship between culture and practice. Practice has long been stressed in social and communication theories, as well as in theories of religion and ritual..$^{90}$ Reproduction of practice is commonly conceptualised in terms of institutions, broadly defined as 'patterns of interaction that govern and constrain the relationships of individuals. ${ }^{91}$ Institutions are thought to do this through the roles that

88 Woolf, 'Only Connect?', 54.

89 For a strong critique of this aspect of network theory, see Mustafa Emirbayer and Jeff Goodwin, 'Network Analysis, Culture, and the Problem of Agency', American Journal of Sociology 99, no. 6 (1994). Interaction does, for instance, not only lead to dissemination or homogenisation, but can reinforce or even solidify group boundaries. See Fredrik Barth, 'Ethnic Groups and Boundaries', in Ethnic Groups and Boundaries: The social organization of culture difference (Boston: Little, Brown and Company, 1969). For new forms of authority, see the emergence of 'holy men' in late antiquity. Peter Brown, 'The Rise and Function of the Holy Man in Late Antiquity', The Journal of Roman Studies 61 (1971); Claudia Rapp, Holy Bishops in Late Antiquity: The Nature of Christian Leadership in an Age of Transition (Berkeley: University of California Press, 2005).

90 Drawing on a range of thinkers, from G. H. Mead, J. L. Austin, and J. Searle (formulated as a historical programme by Q. Skinner), G. Lakoff, M. Foucault, and P. Bourdieu. Recent examples include the symbolic convergence theory (sCT) of E. G. Bormann, the cultural pragmatics of J. Alexander, and the identity-network approach of $\mathrm{H}$. White. Ernest G. Bormann, 'Fantasy and Rhetorical Vision: The Rhetorical Criticism of Social Reality', Quarterly Journal of Speech $5^{8}$ (1972); Jeffrey Alexander, 'Cultural Pragmatics: Social Performance between Ritual and Strategy', Sociological Theory 22, no. 4 (2004); Harrison C. White, Identity and Control: How Social Formations Emerge, 2nd ed. (Princeton, NJ: Princeton University Press, 2008), see esp. 20-62. In the field of religion, e.g. J. Goody, Mary C. Bell, R. F. Campany. See the genealogical work of Manuel A. Vásquez, More Than Belief: A Materialist Theory of Religion (Oxford: Oxford University Press, 2011).

91 This definition is drawn from the neo-institutionalism of Douglass C. North, John J. Wallis, and Weingast R. Barry, Violence and Social Order: A Conceptual Framework for Interpreting Recorded Human History (New York: Cambridge University Press, 2009), 15. 
individuals ('actors') adopt, the norms that define these roles, the sanctions that reinforce them, and the justifications that describe and explain them. ${ }^{92}$ Institutions allow individuals to turn networks into more cohesive groups, ranging from abstract communities to formal organisations. The community's practices are enshrined by symbols - narratives, metaphors, sayings, gestures, etc., - forming a symbolic reservoir that its members recognise and that new members learn in the process of socialisation into the community. By naturalising ('reifying') certain roles and patterns of behaviour, institutions help to (re)produce social worlds. ${ }^{93}$ Individuals internalise (to various degrees) roles through participation in the institutions of different communities, including ethnic, occupational, political, and religious ones, forming what we with Bourdieu may term their 'habitus. ${ }^{94}$ When internalised, their various roles can be conceptualised as identities. ${ }^{95}$ Identities are actualised through the deployment of symbols to elicit modes of thought and behaviour among the people who share the symbolic repertoire. We may label such usage symbolic cues. ${ }^{96}$ Competent actors can - and political or religious authorities are often obliged to - weave symbolic cues together into elaborate displays or symbolic performances. Examples range from sermons to poetry readings to speeches at political rallies. For textual communities, texts play an important role in facilitating such performances. ${ }^{97}$

Both institutions and identities constitute important areas of research within the study of ancient religion. A body of scholarship has emerged that draws on models and comparative material for understanding formal religious institutions in antiquity, through comparisons between ('pagan') voluntary associations, Christ groups, and synagogues. ${ }^{98}$ Simultaneously, many scholars have brought concepts of identity and performance to bear on ancient sources,

92 See Peter L. Berger and Thomas Luckmann, The Social Construction of Reality: A Treatise in the Sociology of Knowledge (New York: Penguin, 1968).

93 Berger and Luckmann, Social Construction, 77; Pierre Bourdieu, Outline of a Theory of Practice (Cambridge: Cambridge University Press, 1977), 164-68.

94 Bourdieu, Outline, 72.

95 See Peter Burke and Jan E. Stets, Identity Theory (Oxford: Oxford University Press, 2009), 38 .

96 This term is drawn from Adam Schor's notion of 'cues' (below), in turn drawing on Bourdieu. The term 'cue' has become widespread in sociological theory, for instance in Symbolic Convergence Theory. See Ernest G. Bormann, John F. Cragan, and Donald C. Shields, 'Three Decades of Developing, Grounding and Using Symbolic Convergence Theory (SCT)', Annals of the International Communication Association 25, no. 1 (2001).

97 While my examples here are confined to verbal ones, symbolic performances can also include elements such as 'scenery', 'stage props', etc. See Alexander, 'Cultural Pragmatics', 544-47.

98 See Philip A. Harland, Associations, Synagogues, and Congregations: Claiming a Place in Ancient Mediterranean Society (Minneapolis: Fortress Press, 2003); Richard S. Ascough, 
as part of the linguistic turn in ancient history. ${ }^{99}$ These two approaches are at times combined. Philip Harland has studied expressions of identity within Christian, Jewish, and 'Pagan' associations. ${ }^{100}$ Adam Schor's study of the fifth-century Nestorian controversy treats the cultural performance of bishop Theodoret of Cyrrhus and how it contributed to shape his network of allied Syrian bishops. ${ }^{101}$ But they are perhaps more often contrasted, especially in studies of lay religious practice. Situationist trends in modern sociology, and the 'lived religion' approach within religious studies, have contributed to a strong scepticism as to the extent to which institutions, both formal and informal group patterns, actually shape coherent 'identities' for most people. ${ }^{102}$ Scholarship of late antique religion drawing on these currents instead emphasise the situational nature of an individual's identification, and the multiple identities that each individual has access to. They often argue that religious institutions generally had a limited effect on lay religious identities. ${ }^{103}$

\subsection{The Study's Approach}

The present study engages with the debate over lay identity by considering to what extent Manichaean institutions affected the religious identity of the villagers in fourth-century Kellis. Using prosopography and network concepts, it traces and analyses the social networks of the central actors of House 1-3, and the social dimensions of the Manichaean community in the Oasis and the village; what social groups it spread through and how far the network extended. In turn, this provides a basis for discussing lay practice and identity in the Kellis papyri. First, by examining religious practices referred or alluded

'What Are They Now Saying About Christ Groups and Associations?', Currents in Biblical Research 13, no. 2 (2015).

99 An important mark was the establishment of the Journal of Early Christian Studies in 1993. For an overview, see Elizabeth A. Clark, History, Theory, Text: Historians and the Linguistic Turn (Cambridge: Harvard University Press, 2004); for such an analysis of Augustine, see Virginia Burrus, "In the Theatre of This Life": The Performance of Orthodoxy in Late Antiquity', in The Limits of Ancient Christianity: Essays in Late Antique Thought and Culture in Honor of R. A. Markus, ed. W. Kingshern and M. Vessey (Ann Arbor: University of Michigan, 1999).

100 Philip A. Harland, Dynamics of Identity in the World of the Early Christians: Associations, Judeans, and Cultural Minorities (New York: T \& T Clark, 20o9).

101 Adam Schor, Theodoret's People: Social Networks and Religious Conflict in Late Roman Syria (Berkley: University of California Press, 2011).

102 For this criticism, Roger Brubaker and Frederick Cooper, 'Beyond Identity', Theory and Society 39, no. 1 (2000).

103 See Rebillard, Christians and Their Many Identities, and, furthermore, Chapter 5 in the present work. 
to in the documents, we catch a glimpse of the daily patterns of interaction that made the network into a religious community. Second, by analysing the religious cues employed by the laity, i.e. their symbolic performances, we get a sense of what characterised the religious identity of this community.

Certainly, several obstacles have to be considered. For one, while we are relatively well-informed about the activities of late antique Christian authorities, such as Theodoret of Cyrrhus, almost nothing is known of the historical developments and institutional context that framed Manichaean activities, apart from what we can glean from the papyri. Moreover, distinguishing between different religious 'identities' in the papyri is a challenge - and identifying particularly Manichaean performances presents additional problems, as Manichaeans shared in much of the Christian symbolic repertoire. ${ }^{104}$ Nonetheless, the documentary texts from Kellis do furnish us with evidence that make this approach worthwhile, as we shall see. They allow us to grasp how the Manichaean community was 'put into practice': how everyday, habitual activities contributed to create a distinctive identity, and to reproduce a local, Manichaean church.

104 And not only Christian ones; as one recent author puts it, 'Mani appears to have made conscious use of the entire symbolic repertoire available to him.' Richard Foltz, Religions of Iran: From Prehistory to Present (London: Oneworld Publications, 2013), 140. For the term 'symbolic repertoire', see ibid., xii-xiii. For recent scholarship on religious expressions in late antique papyri, and categories such as 'Christian' or 'pagan', see Malcolm Choat, Belief and Cult in Fourth-Century Papyri (Turnhout: Brepols, 2006); Lincoln H. Blumell, Lettered Christians: Christians, Letters, and Late Antique Oxyrhynchus (Leiden: Brill, 2012). 